\title{
Evaluation of the Antioxidant Activity and Physiological Functionality of Baegilju
}

\author{
Young Ho Cho ${ }^{1 \dagger}$, Tae Kang Byun ${ }^{1+}$, Jong-Hwa Lee ${ }^{2}$ and Gye Won Lee ${ }^{1}$ *
}

${ }^{1}$ Department of Pharmaceutics \& Biotechnology, Konyang University, Nonsan 320-711, Korea

${ }^{2}$ Division of Research and Development, Korea Institute of Toxicology, Daejeon 305-343, Korea

Received October 10, 2013 /Revised December 3, 2013 /Accepted December 18, 2013

\begin{abstract}
Baegilju is a famous traditional Korean wine made over the course of 100 days. The physiological functionalities of Baegilju were evaluated using different tests. The spectrophotometric method was used to determine the total concentration of polyphenolics and flavonoids and DPPH and ABTS radicals. A nitrite scavenging assay was used to evaluate antioxidant activity. The fibrin plate method was used for fibrinolysis and to evaluate angiotensin I converting enzyme (ACE) inhibitory activity; finally, the colorimetric determination method was used to evaluate acetylcholinesterase (AChE) inhibitory activity. The total polyphenolic content of non-sterilized Baegilju and sterilized Baegilju were $391.59 \mu \mathrm{g}$ and $401.33 \mu \mathrm{g}$ tannic acid equivalents/ml, respectively; and the flavonoids contents were $284.75 \mu \mathrm{g}$ and $308.35 \mu \mathrm{g}$ quercetin equivalents/ml, respectively. Baegilju exhibited more excellent antioxidant activities (DPPH and ABTS radicals, nitrite scavenging activity) than did Cheongju. In addition, the fibrinolytic activity and AChE inhibitory activity were found to be higher in Baegilju than they were in Cheongju. The ACE inhibitory activity of non-sterilized Baegilju, sterilized Baegilju, and Cheongju were $23.62 \%, 19.99 \%$, and $38.91 \%$, respectively. Therefore, these results suggest that Baegilju has potential as an antioxidant agent and anti-thrombosis agent.
\end{abstract}

Key words : Acetylcholinesterase, angiotensin I converting enzyme, antioxidant activity, Baegilju fibrinolysis

\section{서 론}

최근 주류에 관한 연구 중 적정량의 알코올 음료의 섭취는 심장질환 억제, 동맥경화 완화, 고혈압, 당뇨, 암 유발 억제 등 건강 및 질환에 긍정적인 효과가 있는 것으로 보고 되고 있다 $[1,5,12,28,30,35]$. 알코올 음료의 약리효과는 그 원료에 포함되어 있거나 또는 발효과정 중에 생성된 물질의 복합 상 승 작용에 의해 일어날 수 있지만 현재 전통주의 건강 또는 질병과 관련된 생리활성에 관한 여러 가지 속설에 대하여 과 학적인 접근은 미흡한 실정이다. 최근 여러 연구자들은 민들 레[20], 캐모마일[25], 아카시아[34], 구기자[27] 및 로즈마리 [21] 등을 첨가한 전통주를 제조하여 이들의 품질 특성과 생리 기능성을 조사하여 보고하였다. 근래에 소비양상이 점차 다양 화되면서 전통주에 대한 인식, 홍보부족으로 전통주의 소비가 줄고 시장규모는 다소 위축되고 있다[14]. 전통주에 대한 연구 가 활발히 이루어지지 못하여 전통주 제조 방법에 대한 정확

\footnotetext{
${ }^{\dagger}$ Authors contributed equally.

${ }^{*}$ Corresponding author

Tel : +82-41-730-5692, Fax : +82-41-730-5692

E-mail : pckmon@konyang.ac.kr

This is an Open-Access article distributed under the terms of the Creative Commons Attribution Non-Commercial License (http://creativecommons.org/licenses/by-nc/3.0) which permits unrestricted non-commercial use, distribution, and reproduction in any medium, provided the original work is properly cited.
}

한 계승이 제대로 이루어지지 못하였으며 이로 말미암아 전통 주 지정이나 세계시장 진출 등의 문제가 다소 어려움을 겪고 있는 실정이다 $[17,18]$. 이러한 전통주들은 과학적으로 입증된 자료가 부족하고 많은 사람들에게 잘 알려져 있지 않은 상태 이다. 최근 반가주(班家酒)의 복원과 더불어 과학적 우수성을 입증하고자 하는 노력이 증대되고 있다. 반가주는 안동 지방 양반가의 음식문화를 보여주는 3 대 요리서 중 하나인 온주법 (蓝酒法)에 '양반가에서 제조된 양주’라고 수록되어 있다. 반가 주의 종류로는 여러 가지 배꽃이 필 때 담그는 이화주, 반가에 서 대소사 때 쓰던 약주인 황금주, 국화주, 오호주, 적선소주 등이 대표적이라 할 수 있다[22].

백일주의 유래에 대한 자세한 기록은 없으나 19세기 중엽의 것으로 추정되는 저자, 연대 미상의 주방(酒方)이란 책명의 한 글 조리서와 1800 년대 중엽의 것으로 추정되는 한글 조리서인 홍씨주방문(洪氏酒方文)에 '밑술, 덧술은 지애밥의 형태로 하 여 약 100 일이 경과한 후 떠 쓴다라고 백일주의 제조방법이 나온다[23].

본 연구에서는 백일주에 대한 과학적 우수성을 입증하여 전통주에 대한 관심을 증대시키고자 생리 활성으로서 항치매 성 acetylcholinesterase $(\mathrm{AChE})$ 저해 활성, angiotensin 전환 효소(ACE) 저해 활성, 혈전용해 활성 및 항산화 활성으로서 $\mathrm{DPPH}$ 라디칼 소거능, $\mathrm{ABTS}$ 라디칼 소거능, 아질산염 소거능 그리고 살균에 의한 활성 변화 여부를 백일주와 비슷한 과정 으로 제조되어 판매되고 있는 청주와 비교 평가하였다. 


\section{재료 및 방법}

\section{시약 및 재료}

시약으로는 2,2-Diphenyl-1-picrylhydrazyl (DPPH), butylated hydroxyanisole (BHA), modified gries reagent, fibrin from human plasma, acetylcholinesterase $(\mathrm{AChE})$, angiotensin-converting enzyme (ACE) 및 Hip-His-Leu (HHL) acetate salt, 5,5'-dithiobis-(2-nitrobenzoic acid) (DTNB), acetylthiocholine iodide, 2,2'-azinobis-(3-ethylbenzothiazoline-6-sulfonic acid) (ABTS)는 Sigma-Aldrich Chemical (St. Louis, MO, USA)에서, sodium nitrite는 Junsei (Kyoto, Japan) 에서 각각 구입하여 사용하였다. 그 외 실험에 사용된 모든 시약들은 일급 및 특급 시약을 구입하여 사용하였다.

백일주와 대조군으로 사용된 청주는 국내에서 시판되는 제 품을 구입하여 사용하였다.

\section{검체 제조}

실험에 사용한 검체는 찹쌀, 백미, 누룩(혼합균), 재래종 국 화꽃, 오미자, 진달래, 솔잎 및 물을 넣고 저온에서 100 일간 발효 숙성시킨 다음 침전 처리하여 고형분을 제거한 생주(검 체 A) 및 이를 압착하여 찌꺼기를 제거하고 여과, 살균 처리 하여 시판되는 백일주(검체 $\mathrm{B}$ )를 사용하였다. 또한 국산쌀(도 정 배유 부분), 입곡, 주모(효모) 및 물을 넣고 18 일간 발효한 후, 압착하여 찌꺼기(청주박)를 제거하여 여과, 살균 처리하여 약 2-3개월 숙성 과정을 거쳐 제조하여 판매되는 청주(검체 $\mathrm{C})$ 를 대조군으로 사용하였다. 모든 검체는 증발 농축기 (Heidolph, laborata 410, Schwabach, Germany)로 $40^{\circ} \mathrm{C}$ 에서 감압 농축하여 알코올 부분을 제거한 후 다시 증류수를 가해 원래의 부피로 정용하여 검체로 사용하였다.

\section{총 폴리페놀 함량 측정}

총 폴리페놀 함량은 Folin-Denis 방법[10]을 변형하여 측정 하였다. 즉, 적당하게 희석된 시료 $1 \mathrm{ml}$ 에 $95 \%$ ethanol $1 \mathrm{ml}$ 와 증류수 $5 \mathrm{ml}$ 를 첨가하고 $1 \mathrm{~N}$ Folin-Ciocalteu's reagent 0.5 $\mathrm{ml}$ 를 넣어 잘 섞어 주었다. 5 분간 방치한 후, $10 \% \mathrm{Na}_{2} \mathrm{CO}_{3} 1$ $\mathrm{ml}$ 를 가하여 $725 \mathrm{~nm}$ 에서 1시간 이내에 흡광도(UV/Vis spectrophotometer, Thermo Scientific, G10S, Waltham, MA, USA)를 측정하였다. Tannic acid를 표준물질로 사용하였으며 총 폴리페놀 함량은 검체 $1 \mathrm{ml}$ 중의 $\mu \mathrm{g}$ tannic acid로 나타내 었다.

\section{총 플라보노이드 함량 측정}

총 플라보노이드 함량은 Moreno 등[29]의 방법에 의해 측 정하였다. 즉, 각 시료 $0.5 \mathrm{ml}$ 에 $10 \%$ aluminum nitrate 0.1 $\mathrm{ml}, 1 \mathrm{M}$ potassium acetate $0.1 \mathrm{ml}$ 및 ethanol $4.3 \mathrm{ml}$ 를 가하여 혼합하고 실온에서 40 분 동안 정치한 뒤 $415 \mathrm{~nm}$ 에서 흡광도를
측정하였다. Quercetin을 표준물질로 사용하였으며 총 플라보 노이드 함량은 검체 $1 \mathrm{ml}$ 중의 $\mu \mathrm{g}$ quercetin으로 나타내었다.

\section{$\mathrm{DPPH}$ 라디칼 소거능 측정}

$\mathrm{DPPH}$ radical에 대한 소거활성은 Blois의 방법[2]을 변형하 여 측정하였다. 즉, 각 검체 $20 \mu \mathrm{l}$ 에 $0.1 \mathrm{mM} \mathrm{DPPH} 180 \mu \mathrm{l}$ 를 넣고 vortex한 후 30 분 동안 방치한 다음 $560 \mathrm{~nm}$ 에서 흡광도 를 측정하였다. 표준물질로서 L-ascorbic acid를 농도별로 동 량 첨가하였으며 검체의 $\mathrm{DPPH}$ 라디칼 소거능은 표준물질과 비교 산출하여 ascorbic acid equivalents antioxidant capacity 의 약어인 $\mathrm{AEAC}(\mathrm{\mu g} / \mathrm{ml})$ 로 나타내었다[4].

\section{ABTS 라디칼 소거능 측정}

ABTS 라디칼 소거능 측정은 ABTS radical cation decolorization assay법에 따라 시행하였다[31]. 즉, $7.0 \mathrm{mM}$ 의 ABTS 용액과 $2.45 \mathrm{mM}$ 의 potassium persulphate 용액을 24시 간 동안 암소에서 방치하여 ABTS 라디칼을 형성시킨 후, 인산 완충액( $\mathrm{pH} 7.4$ )으로 흡광도가 $734 \mathrm{~nm}$ 에서 $0.7 \pm 0.02$ 가 되도록 희석하여 사용하였다. 희석된 ABTS 라디칼 용액 $1 \mathrm{ml}$ 를 검체 $10 \mu 1$ 에 첨가하여 암소에서 90 분간 반응시킨 후 $734 \mathrm{~nm}$ 에서 흡광도를 측정하였다. $\mathrm{ABTS}$ 라디칼 소거능은 $\mathrm{DPPH}$ 라디칼 소거능과 동일하게 $\mathrm{AEAC}(\mu \mathrm{g} / \mathrm{ml})$ 값으로 검체의 항산화능을 나타내었다.

\section{아질산염(nitrite) 소거능 측정}

아질산염 소거작용은 Kato 등[16]의 방법에 따라 다음과 같 이 측정하였다. 즉, $1 \mathrm{mM}$ 의 $\mathrm{NaNO}_{2}$ 용액 $20 \mu \mathrm{l}$ 에 검체 $80 \mu \mathrm{l}$ 를 첨가하고 $37^{\circ} \mathrm{C}$ 에서 1 시간 동안 반응시켜 얻은 반응액을 40 $\mu \mathrm{l}$ 씩 취하고 여기에 $4 \%$ Griess 시약 $100 \mu \mathrm{l}$ 를 가하여 혼합시켜 빛을 차단한 상태로 실온에서 15 분간 방치시킨 후, 분광 광도 계를 사용하여 $560 \mathrm{~nm}$ 에서 흡광도를 측정하여 잔존하는 아질 산염의 백분율로 나타내었다. 공시험은 Griess 시약 대신 증류 수를 가하여 같은 방법으로 행하였다. Nitrite 소거능은 DPPH 라디칼 소거능과 동일하게 $\mathrm{AEAC}(\mathrm{\mu g} / \mathrm{ml})$ 값으로 검체의 항 산화능을 나타내었다.

\section{혈전용해 활성 측정}

혈 전용해 활성은 Haverkate와 Trass의 fibrin plate법[11]을 일부 변형하여 측정하였다. 즉, 검체 $170 \mu \mathrm{l}$ 에 $0.1 \mathrm{M} \mathrm{Mcllvaine}$ 완충액(pH 7.0)에 $0.6 \%$ fibrin을 녹인 기질용액 $1 \mathrm{ml}$ 를 첨가한 후, $40^{\circ} \mathrm{C}$ 에서 10 분간 반응시켰다. $0.4 \mathrm{M}$ trichloroacetic acid 용액 $1 \mathrm{ml}$ 를 첨가하여 반응 종료 30분 후에 Whatman No. 2 여과지를 이용하여 여과하였다. $30 \mu \mathrm{l}$ 의 여과액에 $0.4 \mathrm{M}$ sodium carbonate 용액 $150 \mu \mathrm{l}, 1 \mathrm{~N}$ folin 시약 $30 \mu \mathrm{l}$ 를 첨가하여, 여과액 중의 tyrosine을 실온에서 30분간 발색시킨 후, microplate reader (Tecan, Sunrise, Durham, NC, USA)를 이용하여 
$660 \mathrm{~nm}$ 에서 흡광도를 측정하였으며 이 때 효소 1 unit은 검체 $1 \mathrm{ml}$ 가 1분 동안에 tyrosine $1 \mu \mathrm{g}$ 을 생산하는 활성으로 표현하 였다.

\section{Acetylcholinesterase 저해활성 측정}

$\mathrm{AChE}$ 저해활성은 Ellman 등[9]의 방법을 일부 변형하여 측정하였다. 즉, 96 well plate에 $140 \mu 1$ 의 $0.1 \mathrm{M}$ 인산 완충액 (pH 8.0), $10 \mu l$ 의 AChE (0.4 unit/ml), $40 \mu 1$ 의 기질액 $(2 \mathrm{mM}$ acetylthiocholine iodide, $0.5 \mathrm{mM} \mathrm{DTNB}$ )과 검체 $10 \mu 1$ 를 각각 첨가한 후, 60 분 동안 반응시켰다(SR). 그리고 검체 대조군으 로 효소대신 완충액 $10 \mu 1$ 를 넣어 함께 반응시켰다(SC). 효소반 응으로는 검체 대신 완충액 $10 \mu 1$ 를 넣어 함께 배양하였으며 (ER), 효소에 대한 대조군으로 효소 대신 완충액 $10 \mu 1$ 를 넣어 함께 배양하였다(EC). 배양한 후 $415 \mathrm{~nm}$ 에서 10, 30, 60분 후에 흡광도를 측정하여 아래의 식으로 저해활성을 계산하였다. Acetylcholinestersase 저해활성 $(\%)=[1-(S R-S C / E R-E C)] \times 100$

\section{Angiotensine 전환효소 저해활성 측정}

$\mathrm{ACE}$ 저해효과 측정은 Cushman과 Cheung $[7,8]$ 의 spectrophotometric assay 방법을 일부 변형하여 측정하였다. 즉, 반응군은 $0.3 \mathrm{M} \mathrm{NaCl}$ 을 함유하는 $0.1 \mathrm{M}$ sodium borate buffer $(\mathrm{pH}$ 8.3)에 기질인 HHL $12.5 \mathrm{mM}$ 을 녹인 액 $100 \mu \mathrm{l}, \mathrm{ACE}(0.06$ $\mathrm{U} / \mathrm{ml}) 100 \mu \mathrm{ll}$ 와 각 검체 용액 $50 \mu \mathrm{l}$ 를 충분히 혼합하였다. 대조 군은 검체 대신 증류수 $0.1 \mathrm{ml}$ 를 첨가하여 $37^{\circ} \mathrm{C}$ 에서 30 분간 반응시키고, $1 \mathrm{~N} \mathrm{HCl} 0.25 \mathrm{ml}$ 첨가로 반응을 중지시킨 뒤 1.5 $\mathrm{ml}$ 의 ethyl acetate를 첨가하여 5 분 동안 혼합한 후, $3,000 \mathrm{rpm}$ 으로 15 분간 원심 분리하여 상등액 $1.0 \mathrm{ml}$ 를 취하였다. $120^{\circ} \mathrm{C}$ 에서 15 분 동안 ethyl acetate를 휘발시킨 후, 잔사에 증류수 $1.5 \mathrm{ml}$ 를 첨가하여 1 시간 동안 완전히 추출된 hippuric acid를 분광광도계를 사용하여 $228 \mathrm{~nm}$ 에서 흡광도를 측정한 후, 다음 식에 따라 저해율 $(\%)$ 을 구하였다.

저해율 $(\%)=[1$-(반응군의 hippuric acid의 생성량/대조군의 hippuric acid의 생성량)] $\times 100$

\section{통계처리}

모든 실험은 3회 반복 실험하였으며 Ducan's multiple range test를 행하여 각 시험군의 평균과 표준편차를 산출하고 각 시험군 간의 유의성을 $5 \%(p<0.05)$ 유의 수준에서 검증하였 다.

\section{결과 및 고찰}

\section{총 폴리페놀 및 플라보노이드 함량 변화}

폴리페놀이란 녹색식물이 광합성 작용을 할 때 생성된 탄수 화물의 일부가 변화한 2 차 대사산물로 식물계에 8,000 여 개의 구조를 가진 성분으로 존재하며 페놀성 화합물이라고도 한다. 분자 내 페놀성 수산기가 효소 단백질과 같은 거대 분자들과
Table 1. The total polyphenolic and flavonoids contents of the alcoholic beverages

\begin{tabular}{ccc}
\hline Samples & $\begin{array}{c}\text { Polyphenolics } \\
(\mu \mathrm{g} \text { tannic acid } / \mathrm{ml})^{1)}\end{array}$ & $\begin{array}{c}\text { Flavonoids } \\
(\mu \mathrm{g} \text { quercetin } / \mathrm{ml})^{2)}\end{array}$ \\
\hline A & $401.33 \pm 20.89$ & $308.35 \pm 10.51$ \\
B & $391.59 \pm 15.18$ & $284.75 \pm 15.88$ \\
C & $76.72 \pm 4.37$ & $175.55 \pm 16.62$ \\
\hline
\end{tabular}

${ }^{1)}$ Mean of triplicate determinations \pm SD expressed as $\mu \mathrm{g}$ tannic acid equivalents per $1 \mathrm{ml}$ of alcoholic beverages.

${ }^{2)}$ Mean of triplicate determinations \pm SD expressed as $\mu \mathrm{g}$ quercetin equivalents per $1 \mathrm{ml}$ of alcoholic beverages.

A: non-sterilized Baegilju, B: sterilized Baegilju, C: Cheongju.

결합하는 성질이 있기 때문에 항산화 작용, 항암 및 콜레스테 롤 저하작용 등의 다양한 생리활성을 가지는 것으로 알려져 있다[13]. 또한, 플라보이드는 항균, 항암 및 항염증 활성 등이 보고되어 있다[3].

백일주 및 청주의 총 폴리페놀과 플라보노이드 함량 변화를 측정하기 위하여 표준물질로 tannic acid와 quercetin을 각각 사용하였다. 그 결과 Table 1에서와 같이 백일주의 총 폴리페 놀 함량은 살균여부와 상관없이 $401.33 \mu \mathrm{g} \mathrm{TAE} / \mathrm{ml}$ (검체 $\mathrm{A}$ ) 와 $391.59 \mu \mathrm{g} \mathrm{TAE} / \mathrm{ml}$ (검체 B)로 나타났다. 청주의 경우 76.72 $\mu \mathrm{g} \mathrm{TAE} / \mathrm{ml}$ 로 백일주에 비해 5 배 이상 낮은 함량의 폴리페놀 을 함유하는 것으로 나타났다. 또한 플라보노이드 함량도 이 와 유사한 경향을 보였다. 즉, 백일주의 플라보노이드 함량은 $308.35 \mu \mathrm{g} \mathrm{QE} / \mathrm{ml}$ (검체 $\mathrm{A}$ )와 $284.75 \mu \mathrm{g} \mathrm{QE} / \mathrm{ml}$ (검체 $\mathrm{B}$ )로 $175.55 \mu \mathrm{g} \mathrm{QE} / \mathrm{ml}$ 의 청주 보다 높은 것으로 나타났다. 이는 처리과정에서 쌀을 주원료로 하여 제조되는 청주와 달리 국 화, 오미자, 진달래, 솔잎 등의 재료를 넣어 제조되는 백일주의 경우 이들의 영향으로 총 폴리페놀과 플라보노이드 함량이 증가된 것으로 사료된다.

\section{항산화 활성}

백일주 및 청주의 항산화 활성은 DPPH 라디칼 소거능, ABTS 라디칼 소거능, 아질산염(nitrite) 소거능을 가지고 측정 하였다. DPPH 라디칼 소거능은 DPPH 라디칼 특유의 보라색 이 백일주 및 청주 내 항산화제의 작용에 의하여 수소 혹은 전자를 받음으로써 안정한 형태의 화합물로 전환되어 라디칼 용액이 옅은 노란색으로 변하는 것을 원리로 분석하였다. 본 연구에서는 DPPH 라디칼 소거능은 표준물질로 비타민 C를 사용하여 $\mathrm{AEAC}$ 값으로 산출하였으며 그 결과는 Table 2와 같다. 이 때 $12.5 \sim 100 \mu \mathrm{g} / \mathrm{ml}$ 의 범위에서 작성한 검량선의 상 관계수는 0.9963 으로 양호한 직선성을 나타내었다. $\mathrm{AEAC}$ 값 이 가장 높은 대조물질로 사용한 BHA의 경우 $58.04 \mu \mathrm{g}$ ascorbic acid equivalent $/ \mathrm{ml}$ 로 표현이 되는데 이것은 $\mathrm{ml}$ 당 ascorbic acid $58.04 \mu \mathrm{g}$ 과 동일한 항산화력을 가진다는 것을 의미한 다. 백일주의 경우 살균여부와 상관없이 $49.64 \mathrm{AEAC}$ (검체 
Table 2. Antioxidant activity of alcoholic beverages on DPPH radical scavenging

\begin{tabular}{cc}
\hline Samples & DPPH $(\text { AEAC, } \mu \mathrm{g} / \mathrm{ml})^{1)}$ \\
\hline BHA $^{2)}$ & $58.04 \pm 5.70^{* 3}$ \\
A & $49.64 \pm 2.91^{*}$ \\
B & $49.34 \pm 4.05^{*}$ \\
C & $6.65 \pm 2.91$
\end{tabular}

${ }^{1)} \mathrm{DPPH}$ radical scavenging activity.

${ }^{2)}$ The DPPH radical scavenging of BHA, positive control was showed $58.04 \mathrm{AEAC}$ at $100 \mu \mathrm{g} / \mathrm{ml}$.

${ }^{3)}$ Mean of triplicate determinations \pm SD expressed as $\mu \mathrm{g}$ ascorbic acid equivalents per $1 \mathrm{ml}$ of alcoholic beverages. ${ }^{*} p<0.05$ compared with control.

A: non-sterilized Baegilju, B: sterilized Baegilju, C: Cheongju.

$\mathrm{A}$ )와 49.34 $\mathrm{AEAC}$ (검체 B)로 대조물질로 사용된 $\mathrm{BHA}$ 와 비슷 한 $\mathrm{DPPH}$ 라디칼 소거능을 나타내었다. 청주의 경우 6.65 $\mathrm{AEAC}$ (검체 $\mathrm{C}$ )로 백일주에 비해 매우 낮은 $\mathrm{DPPH}$ 소거능을 나타내었다.

ABTS 라디칼 소거능은 potassium persulfate와의 반응에 의해 생성된 $\mathrm{ABTS}$ 라디칼이 시료의 항산화력 물질에 의해 제거되어 라디칼 특유의 색인 청록색이 탈색되는 것을 이용한 측정법이다. 이 방법은 수소공여 항산화제와 연쇄 절단형 항 산화제 모두를 측정할 수 있고, 수용상과 유기상 모두에 적용 이 가능하며 표준물질을 사용함으로써 시료 간 상대비교가 가능하다[31]. 마찬가지로 ascorbic acid를 사용하여 ABTS 라 디칼 소거능을 AEAC 값으로 산출하였다. Table 3에 나타낸 바와 같이 백일주의 경우 살균여부와 상관없이 $300.8 \mathrm{AEAC}$ (검체 $\mathrm{A}$ )와 $308.11 \mathrm{AEAC}$ (검체 $\mathrm{B}$ )로 대조물질로 사용된 $\mathrm{BHA}$ 의 $196.08 \mathrm{AEAC}$ 보다 약 1.6배, 청주의 $157.42 \mathrm{AEAC}$ 보다 약 2 배 정도 높은 우수한 ABTS 라디칼 소거능을 보였다.

이는 처리과정에서 쌀을 주원료로 하여 제조되는 청주와 달리 국화, 오미자, 진달래, 솔잎 등의 재료를 넣어 제조되는 백일주의 경우 이들 첨가제에 함유되어 있는 플라보노이드

Table 3. Antioxidant activity of alcoholic beverages on ABTS radical scavenging

\begin{tabular}{cc}
\hline Samples & ABTS $(\text { AEAC, } \mu \mathrm{g} / \mathrm{ml})^{1)}$ \\
\hline BHA $^{2)}$ & $196.08 \pm 12.11^{* 3}$ \\
A & $300.80 \pm 5.94^{*}$ \\
B & $308.11 \pm 4.60^{*}$ \\
C & $157.42 \pm 12.03^{*}$ \\
\hline
\end{tabular}

\footnotetext{
${ }^{1)}$ ABTS radical scavenging activity.

${ }^{2)}$ The ABTS radical scavenging of BHA, positive control was showed $196.08 \mathrm{AEAC}$ at $100 \mathrm{\mu g} / \mathrm{ml}$.

${ }^{3)}$ Mean of triplicate determinations \pm SD expressed as $\mu \mathrm{g}$ ascorbic acid equivalents per $1 \mathrm{ml}$ of alcoholic beverages. " $p<0.05$ compared with control.
}

A: non-sterilized Baegilju, B: sterilized Baegilju, C: Cheongju.
성분들의 작용으로 항산화 활성을 증가시키는 것으로 사료된 다. Choi 등[4]은 국내산과 수입산 포도주의 항산화 활성을 비교한 연구에서 폴리페놀의 함량이 높을수록 항산화 활성이 높게 나타났다고 보고하였다.

아질산염은 식육 등에 첨가하여 색상유지, 독소 및 산패 형 성을 억제하는데 널리 이용되고 있으나, 아민을 함유하고 있 는 음식물을 섭취했을 때 발암성 물질인 nitrosamine을 생성 하는 것으로 알려져 있다. 이 nitrosamine의 일부가 체내에서 diazoalkane으로 전환되어 헥산이나 단백질 또는 세포내 성분 을 알킬화함으로써 암을 유발하기도 하고 아질산염은 그 자체 가 독성을 나타내어 일정 농도 이상 섭취하게 되면 hemoglobin이 산화되어 methemoglobin을 형성하는 methemoglobin증 등의 중독을 일으키는 것으로 알려져 있다[19, 26]. 이러한 nitrosamine 생성 반응은 아질산염과 반응할 수 있는 화합물에 의해 억제될 수 있다. 아질산염의 소거능 측정은 반감기가 극 히 짧은 $\mathrm{NO}$ 의 생성을 정량적으로 유추할 수 있다. 아질산염 소거능 역시 ascorbic acid를 사용하여 AEAC 값으로 나타내 었으며 그 결과는 Table 4 에 나타내었다. 아질산염 소거능은 $\mathrm{DPPH}$ 라디칼 소거능 및 $\mathrm{ABTS}$ 라디칼 소거능과 마찬가지로 백일주의 경우 $103.38 \mathrm{AEAC}$ (검체 $\mathrm{A}$ )와 137.57 $\mathrm{AEAC}$ (검체 B)로 청주의 $99.29 \mathrm{AEAC}$ 보다 높은 아질산염 소거능을 보였 다. 일반적으로 Cooney와 Ross [6]는 phenolic, guaiacol, resorcinol 등의 페놀성 물질은 nitros화 반응을 강력하게 억제한 다고 하였으며, Kato 등[16]은 아질산염 소거능이 있는 물질은 페놀성 화합물 또는 melanoidin이 관여하는 것으로 보고하였 는데 본 실험에서도 쌀과 효모만 들어간 청주 검체보다는 국 화, 오미자, 진달래, 솔잎 등이 들어간 백일주 검체에서 조금 더 높은 활성을 나타내는 것으로 보아 이는 국화, 오미자, 진달 래, 솔잎 등에 함유된 페놀성 화합물의 작용으로 사료된다.

\section{혈전용해 활성}

Yun 등[38]의 보고에 의하면 생체내의 혈액은 응고와 용해 작용이 항상성을 이루고 있어 정상적으로 순환되고 있을 때에 는 혈전이 생성되지 않지만 여러 가지 원인으로 이 항상성이 깨져 혈전이 생성되면 혈관이 막히게 되고 혈액 순환이 방해

Table 4. Antioxidant activity of alcoholic beverages on nitrite scavenging

\begin{tabular}{cc}
\hline Samples & Nitrite $(\mathrm{AEAC}, \mu \mathrm{g} / \mathrm{ml})^{1)}$ \\
\hline A & $103.38 \pm 3.13^{* 2}$ \\
B & $137.57 \pm 1.71^{*}$ \\
C & $99.29 \pm 2.98^{*}$
\end{tabular}

\footnotetext{
${ }^{1)}$ Nitrite scavenging activity.

${ }^{2)}$ Mean of triplicate determinations $\pm \mathrm{SD}$ expressed as $\mu \mathrm{g}$ ascorbic acid equivalents per $1 \mathrm{ml}$ of alcoholic beverages. " $p<0.05$ compared with control.

A: non-sterilized Baegilju, B: sterilized Baegilju, C: Cheongju.
} 


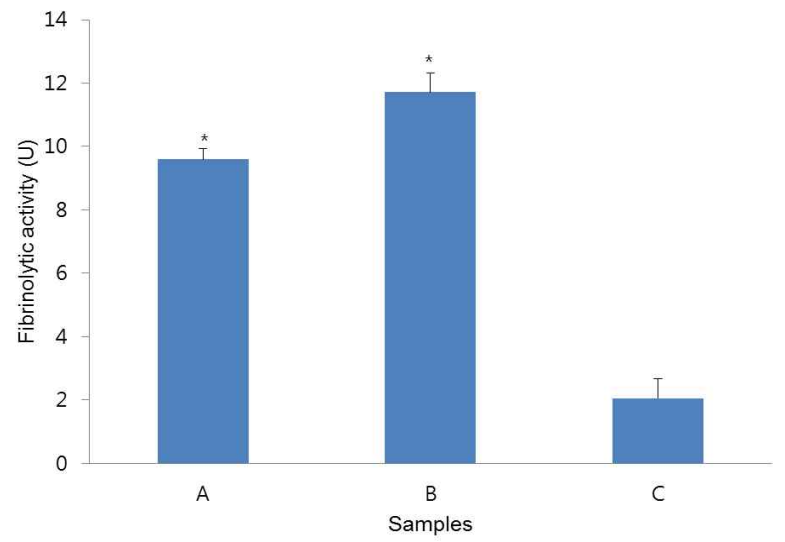

Fig. 1. Effects of alcoholic beverages on the fibrinolytic activity. All values were expressed as the average of triplicate samples with SD. ${ }^{*} \times 0.05$ compared with control. A: nonsterilized Baegilju, B: sterilized Baegilju, C: Cheongju.

되어 영양분과 산소공급에 영향을 끼쳐 심부전증이나 심장질 환 등의 혈전증(thrombosis)으로 사망하는 것으로 알려져 있 다. 혈전 형성을 방지하기 위해서는 혈소판 응집을 억제하거 나 혈전을 용해할 필요가 있다.

따라서 백일주와 청주의 생체 내에 생성된 혈전을 용해시켜 뇌 혈관질환 및 혈액순환 차단을 예방하는 혈전용해 활성을 측정한 결과를 Fig. 1에 나타내었다. 살균 후의 백일주(검체 $\mathrm{B})$ 와 살균 전의 백일주(검체 $\mathrm{A})$ 의 경우 혈전용해 활성이 11.72 $\mathrm{U}$ 과 $9.60 \mathrm{U}$ 로 각각 나타나 청주(검체 $\mathrm{C}, 2.05 \mathrm{U}$ )보다 약 7 9 $\mathrm{U}$ 정도 높은 혈전용해 활성을 나타내었다. $\mathrm{Yu}$ 등[37]은 시판 주류의 생리 기능성 연구에서 시판 주류의 혈전용해 활성이 최고 $26.8 \mathrm{U}$ 에서 최저 $0 \mathrm{U}$ 사이였다고 보고하였는데, 직접적 인 비교는 힘들겠지만 본 연구에서 나타난 약 $10 \mathrm{U}$ 정도의 백일주의 활성은 어느 정도 혈전용해 가능성이 있는 것으로 사료된다.

\section{Acetylcholinesterase 저해 활성}

인지기능저하는 체내의 대표적인 신경전달물질인 acetylcholine (ACh)의 부족이 주요 원인 중 하나라고 알려져 있 다. $\mathrm{ACh}$ 는 신경말단에서 자극 전달이 끝나면 $\mathrm{AChE}$ 의 작용으 로 choline과 acetate로 분해되고 이것은 choline acetyltransferase (ChAT)의 작용으로 acetyl $\mathrm{CoA}$ 와 choline으로부 터 합성된다. 따라서 체내의 신경전달이 원활하게 이루어지려 면 $\mathrm{ACh}$ 에 영향을 미치는 $\mathrm{AChE}$ 와 $\mathrm{ChAT}$ 의 활성이 중요한 것 으로 알려져 있다[36]. 백일주의 항치매 활성의 가능성을 알아 보기 위하여 $\mathrm{AChE}$ 의 저해 활성을 측정하였다(Fig. 2). 그 결과 살균 처리하지 않은 백일주(검체 $\mathrm{A}$ )와 청주(검체 $\mathrm{C}$ )의 경우 $\mathrm{AChE}$ 이 각각 $14.29 \%$ 와 $19.24 \%$ 로 비슷한 수준으로 나타났으 나, 살균 처리한 백일주(검체 B)의 경우 $35.07 \%$ 의 $\mathrm{AChE}$ 저해 활성을 나타내었다( $p>0.05)$. Jung 등[15]은 여러 가지 약용식 물 추출물의 라디칼 소거능과 $\mathrm{AChE}$ 저해 활성 비교 연구에서

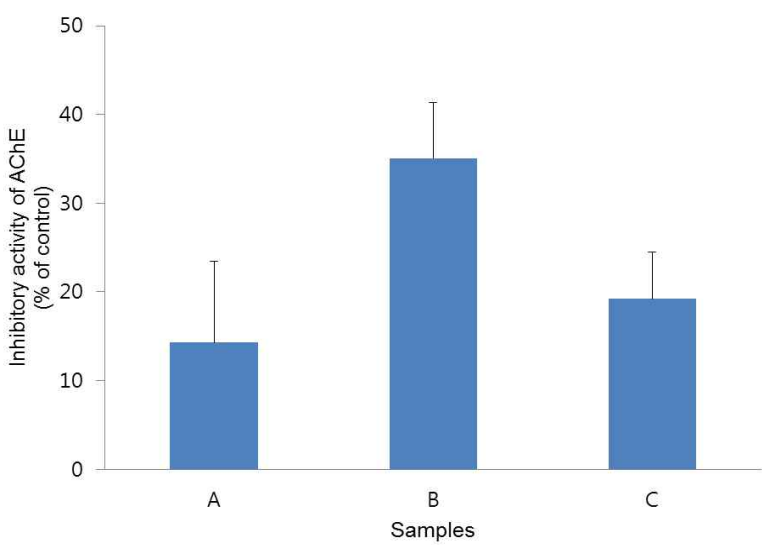

Fig. 2. Inhibitory effect of the alcoholic beverages on acetylcholinesterase activity. All values were expressed as the average of triplicate samples with SD. A: non-sterilized Baegilju, B: sterilized Baegilju, C: Cheongju.

$\mathrm{AChE}$ 저해 활성이 높았던 추출물은 강한 항산화 효과를 가진 다고 보고하였는데 이는 항산화능과 $\mathrm{AChE}$ 저해활성과의 상 관관계를 시사해 주는 결과라 할 수 있다. 따라서 살균 처리한 백일주의 $\mathrm{AChE}$ 의 저해 활성도 아질산염 소거능에 기인하는 것으로 사료된다.

\section{Angiotensine 전환효소 저해 활성}

$\mathrm{ACE}$ 는 체내 혈압 조절계에서 엔지오텐신 I 을 I로 전환 시키는 것을 촉매하는 효소로 근래에 $\mathrm{ACE}$ 저해제를 이용한 고혈압 예방용 건강식품이나 한방 의약품 개발에 관한 연구가 활발히 진행되고 있다[34]. 백일주 및 청주의 $\mathrm{ACE}$ 저해 활성 을 측정한 결과 Fig. 3에 나타낸 바와 같이 백일주(검체 A, $\mathrm{B})$ 의 경우 $\mathrm{ACE}$ 저해활성은 $23.62 \%$ 와 $19.99 \%$ 이었으며, 청주 (검체 C)의 경우 $38.91 \%$ 로 백일주에 비해 약 2 배 이상의 높은

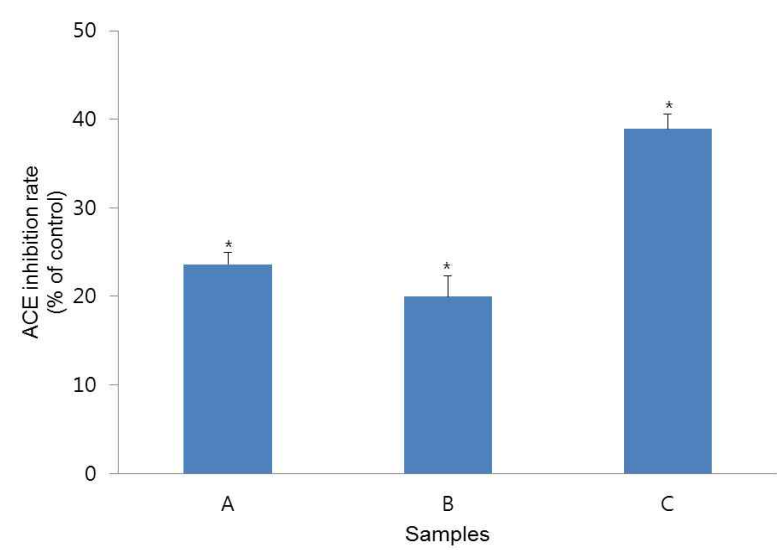

Fig. 3. Inhibitory effect of the alcoholic beverages on angiotensin I-converting enzyme activity. All values were expressed as the average of triplicate samples with SD. ${ }^{*} \not<0.05$ compared with control. A: non-sterilized Baegilju, B: sterilized Baegilju, C: Cheongju. 
저해활성을 나타내었다( $\beta<0.05)$. ACE 저해물질의 대부분은 펩타이드로 알려져 있는데 $[24,32,33]$, 본 연구에서도 마찬가 지로 전통주들의 주원료인 쌀이나 일부 약용식물에 함유되어 있는 항고혈압성 올리고 펩타이드 또는 전통주의 원료에 함유 되어 있는 단백질이 발효 중 분해되어 항고혈압성 $\mathrm{ACE}$ 저해 펩타이드를 생성하여 효과를 나타내는 것이라 사료된다.

이상의 결과를 바탕으로 전통주에 대한 살균 처리 방법은 생리 기능성과 항산화 활성에 영향을 미치지 않는 타당한 방 법이었으며, 생리 기능성에 대한 기전은 본 연구 이외에도 다 양하므로 추후에 좀 더 연구하여 전통주의 우수성을 과학적으 로 입증하는 것이 필요할 것이라고 사료된다.

\section{References}

1. Arimoto-Kobayashi, S., Sugiyama, C., Harada, N., Takeuchi, M., Takemura, M. and Hayatsu, H. 1999. Inhibitory effects of beer and other alcoholic beverages on mutagenesis and DNA adduct formation induced by several carcinogens. $J$ Agric Food Chem 47, 221-230.

2. Blois, M. S. 1958. Antioxidant determination by the use of a stable free radical. Nature 181, 1199-1200.

3. Cha, J. Y., Kim, S. Y., Jeong, S. J. and Cho, Y. S. 1999. Effects of hesperetin and naringenin on lipid concentration in oratic acid treated mice. J Life Sci 9, 389-394.

4. Choi, Y. M., Yu, K. W., Han, N. S., Koh, J. H. and Lee, J. S. 2006. Antioxidant activities and antioxidant compounds of commercial red wines. J Korean Soc Food Sci Nutr 35, 1286-1290.

5. Clifford, A. J., Ebeler, S., Ebeler, J. D., Bills, N. D., Hinrichs, S. H., Teissedre, P. L. and Waterhouse, A. L. 1996. Delayed tumor onset in transgenic mice fed an amino acid-based diet supplemented with fed an amino acid-based diet supplemented with red wine solids. Am J Cin Nutr 64, 748-756.

6. Cooney, R. V. and Ross, P. D. 1987. N-Nitrosation and N-nitrosamine of morpholine by nitrogen dioxide in aqueous solution: Effects of vanillin and related phenols. J Agric Food Chem 35, 789-793.

7. Cushman, D. W. and Cheung, H. S. 1971. Spectrophotometric assay and properties of the angiotensin-converting enzyme of rabbit lung. Biochem Phamacol 20, 1637-1648.

8. Cushman, D. W. and Ondetti, M. A. 1980. Inhibitors of angiotensin converting enzyme for treatment of hypertension. Biochem Pharmacol 29, 1871-1187.

9. Ellman, G. L., Courtney, K. D., Andres, V. and Featherstne, R. M. 1961. A new and rapid colorimetric determination of acetylcholinesterase activity. Biochem Pharmacol 7, 68-75.

10. Follin, A. D. and Denis, W. 1915. A colorimetric method for the determination of phenols and phenol derivatives in urine. J Biol Chem 22, 305-308.

11. Harverkate, F. and Trass, D. W. 1974. Dose-response curves in the fibrin plate assay, Fibrinolytic activity of protease. Thromb Diath Haemost 32, 356-365.

12. Hayek, T., Fuhrman, B., Vaya, J., Rosenblat, M., Belinky, P.,
Coleman, R., Elis, A. and Aviram, M. 1997. Reduced progression of atherosclerosis in apoplipoprotein E-deficient mice following consumption of red wine, or its polyphenols quercetin or catechin is associated with reduced susceptibility of LDL to oxidation and aggregation. Arterioscler Thromb Vasc Biol 17, 2744-2752.

13. Jeong, H. J., Park, S. B., Kim, S. and Kim, H. K. 2007. Total polyphenol content and antioxidative activity of wild grape (Vitis coignetiae) extracts depending on ethanol concentrations. J Korean Soc Food Sci Nutr 36, 1491-1496.

14. Jun, Y. M., Ahn, Y. S. and Kim, M. H. 2006. The study on the cases of merchandising and suggestions for improving competitive power of traditional liquor. Korean J Comm Living Sci 17, 3-14.

15. Jung, Y. S., Park, S. J., Kim, J. E., Yang, S. A., Park, J. H., Kim, J. H., Jhee, K. H., Lee, S. P. and Lee, I. S. 2012. A comparative study of GABA, glutamate contents, acetylcholinesterase inhibition and antiradical activity of the methanolic extracts from 10 edible plants. Korean J Food SCi Technol 44, 447-451.

16. Kato, H., Lee, I. E., Chuyen, N. V., Kim, S. B. and Hayase, F. 1987. Inhibition of nitrosamine formation by nondialyzable melanoidines. Agric Biol Chem 51, 1333-1338.

17. Kim, H. R. and Ahn, B. H. 2001. Research trend of Korean traditional alcoholic beverage. Food Ind Nutr 6, 5-10.

18. Kim, I. H., Park, W. S. and Koo, Y. J. 1996. Comparison of fermentation characteristics of Korean traditional alcoholic beverage with different in culture. Korean J Diet Culture 11, 339-348.

19. Kim, J. H., Lee, D. H., Jeong, S. C., Chung, K. S. and Lee, J. S. 2004. Characterization of antihypertensive angiotensin I -converting enzyme inhibitor from S. cerevisiae. J Microbiol Biotechnol 14, 1318-1323.

20. Kim, J. H., Lee, S. H., Kim, N. H., Choi, S. Y., Yoo, J. Y. and Lee, J. S. 2000. Manufacture and physiological functionality of Korean traditional liquors by using dandelion. Korean J Appl Microbiol Biotechnol 28, 367-371.

21. Kim, J. S., Kwak, E. J. and Lee, Y. S. 2006. Effect on the quality characteristics of Korean traditional wines with the addition of rosemary (Rosmariuns officinalis L.). Korean J Food Cook Sci 22, 914-922.

22. Kim, K. Y. and Lee, S. W. 1988. Analytical study on the cooking in 'On Zu Bub'. Korean J Diet Culture 3, 143-151.

23. Kim, S. M. and Lee, S. W. 1990. A study on the cooking in 'The Joobang'. Korean J Diet Culture 5, 415-423.

24. Koo, K. C., Lee, D. H., Kim, J. H., Yu, H. E., Park, J. S. and Lee, J. S. 2006. Production and characterization of antihypertensive angiotensin I-converting enzyme inhibitor from Pholiota adipose. J Microbiol Biotechnol 16, 757-763.

25. Lee, D. H., Kim, J. H., Kim, N. M. and Lee, J. S. 2002. Manufacture and physiological functionality of Korean traditional liquors by using chamomile (Matricaria chanmomile). Korean J Food Sci Technol 34, 109-113.

26. Lee, D. H., Kim, J. H., Park, J. S., Choi, Y. J. and Lee, J. S. 2004. Isolation and characterization of a novel angiotensin I -converting enzyme inhibitory peptide derived from the 
edible mushroom Tricholoma giganteum Peptides 25, 621-627.

27. Lee, D. H., Park, W. J., Lee, B. C., Lee, J. C., Lee, D. H. and Lee, J. S. 2005. Manufacture and physiological functionality of Korean traditional wine by using gugija (Lycii Fructus). Korean J Food Sci Technol 37, 789-794.

28. Miyagi, Y., Miwa, K. and Inoue, H. 1997. Inhibition of human low-density lipoprotein oxidation by flavonoids in red wine and grape juice. Am J Cardiol 80, 1627-1631.

29. Moreno, M. I., Isla, M. I., Sampeiettro, A. R. and Vatuone, M. A. 2000. Comparison of the free radical-scavenging activity of propolis from several regions of Argentina. $J$ Enthnopharmacol 71, 109-114.

30. Pace-Asicak, C. R., Hahn, S., Diamandis, E. P., Soleas, G. and Goldberg, D. M. 1995. The red wine phenolics trans-resveratrol and quercetin block human platelet aggregation and eicosanoid synthesis: Implications for protection against coronary heart disease. Clin Chim Acta 235, 207-219.

31. Re, R., Pellegrini, N., Proteggente, A., Pannala, A., Yang, M. and Rice-Evans, C. 1999. Antioxidant activity applying an improved ABTS radical cation decolorization assay. Free Radical Bio Med 26, 1231-1237.

32. Rhyu, M. R., Nam, Y. J. and Lee, H. Y. 1996. Screening of angiotensin I-converting enzyme inhibitors in cereals and legumes. J Biotechnol 5, 334-337.

33. Saito, Y., Nakamura, K., Kawato, A. and Imayasu, S. 1994. Structure and activity of angiotensin I converting enzyme inhibitory peptides from sake and sake less. Biosci Biotech Biochem 58, 1767-1771.

34. Seo, S. B., Kim, J. H., Kim, N. M., Choi, S. Y. and Lee, J. S. 2002. Effect of acasia (Robinia pseudo-acasia) flower on the physiological functionality of Korean traditional rice wine. Korean J Microbiol Biotechnol 30, 410-414.

35. Stoewsand, G. S., Anderson, J. and Munson, L. 1991. Inhibition by wine of tumorigenesis induced by ethyl carbamate (urethane) in mice. Food Chem Toxicol 29, 291-295.

36. Vincenzo, N. T. 2001. Acetylcholinesterase in Alzheimer's disease. Mech Ageing Dev 122, 1961-1969.

37. Yu, H. E., Lee, D. H., Lee, J. H., Choi, S. Y. and Lee, J. S. 2005. Quality characteristics and cardiovascular activities of Korean traditional wines and liquors. Food Sci Biotechnol 14, 772-777.

38. Yun, Y. P., Kang, W. S. and Lee, M. Y. 1996. The antithrombotic effects of green tea catechins. J Food Hyg Safe 11, 77-82.

\title{
초록 : 백일주의 항산화 활성 및 생리기능성 평가
}

\author{
조영호 ${ }^{1}$ - 변태강 ${ }^{1} \cdot$ 이종화 ${ }^{2} \cdot$ 이계원 ${ }^{1}$ * \\ ('건양대학교 제약생명공학과, ${ }^{2}$ 안전성평가연구소)
}

백일주는 찹쌀, 백미, 누룩, 재래종 국화꽃, 오미자, 진달래, 솔잎 및 물을 넣고 100 일간 발효 숙성시킨 전통주이 다. 본 연구에서 백일주의 생리활성을 알아보기 위하여 총 폴리페놀과 플라보노이드 함량, 항산화 활성(DPPH 라 디칼, ABTS 라디칼, 아질산염 소거활성), 혈전용해활성, angiotensisn 전환효소 저해활성 및 acetylcholinesterase 저해활성을 평가하였다. 살균 처리되지 않은 백일주와 살균 처리된 백일주의 총 폴리페놀 함량은 391.59 와 401.33 $\mu \mathrm{g}$ tannic acid equivalents/ml이었고, 총 플라보노이드 함량은 284.75 와 $308.35 \mu \mathrm{g}$ quercetin equivalents $/ \mathrm{ml}$ 이었 다. 백일주의 항산화 활성( $\mathrm{DPPH}$ 라디칼, $\mathrm{ABTS}$ 라디칼, 아질산염 소거활성)은 청주 보다 우수한 것으로 나타났다. 또한 백일주의 혈전용해활성과 acetylcholinesterase 저해활성도 청주에 비해 우수한 것으로 나타났다. 반면에 angiotensin 전환효소 저해활성을 측정한 결과 살균 처리되지 않은 백일주는 $23.62 \%$, 살균 처리된 백일주는 $19.99 \%$, 청주는 $38.91 \%$ 로 청주가 가장 높은 것으로 나타났다. 따라서 본 연구 결과는 백일주가 항산화 효과와 혈전용해 활성이 있음을 시사하고 있다. 